\title{
Accountability Failures and the Decentralisation of Service Delivery in Pakistan
}

\section{Shandana Khan Mohmand and Ali Cheema}

\begin{abstract}
1 Introduction
Easterly (2003) has succinctly described Pakistan's 50-year development experience as the paradox of growth without development. This paradox is in recognition of the fact that Pakistan's successful performance has not been able to translate into meaningful social development for a majority of its citizens. Pakistan has been the fastest growing country in the region during the past 50 years and its growth rates have been more in line with East Asian than with South Asian economies (Figure 1).
\end{abstract}

However, there is a stark contrast between Pakistan's growth success and its social development failure. Pakistan ranks 135 out of 177 countries on the 2005 Human Development Index (UNDP 2005). It has consistently under-performed, relative to comparative economies at similar income levels, across a range of social development indicators (Easterly 2003). For example, during its first 50 years, compared with economies at similar income levels, Pakistan had 20 per cent fewer elementary schoolage children enrolled in primary schools and 24 per cent more of its population is illiterate relative to comparative economies. Furthermore, the primary and secondary education enrolment shortfall is largely explained by a massive shortfall in female enrolment. Similarly, 23 per cent fewer of Pakistan's population have access to sanitation relative to comparative countries and the sanitation shortfall is acute both in rural and urban areas (Easterly 2003: 442-7).

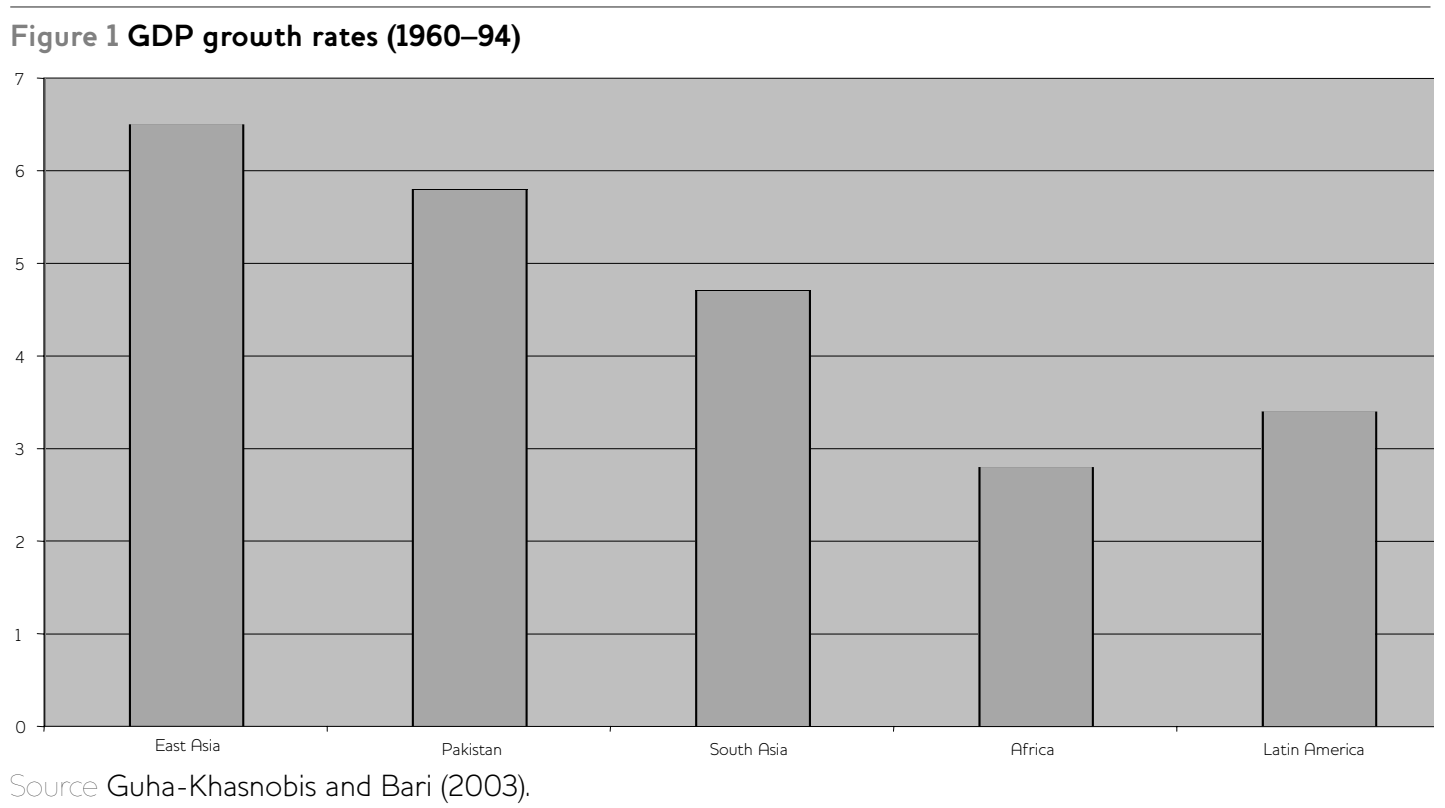

IDS Bulletin Volume 38 Number 1 January 2007 (c) Institute of Development Studies 
Much of this failure has been blamed on little financial outlay by the state for social services and on a lack of prioritisation for service delivery (e.g. education, heath services), due in large part to disproportionately large spending on defence and debt repayment. Recent literature also sees Pakistan's poor social development outcomes as a consequence of the political and administrative structures that weakened political and bureaucratic accountability to citizens and resulted in political economy and governance failures. These structures were characterised by: (a) centralisation,

(b) bureaucratisation, and (c) clientelist politics, and under this system, which persisted through both military and civilian regimes, most decisions regarding service delivery, including budgetary allocations, were in the hands of the provincial and federal governments. Local governments (functioning under the military regimes of Ayub and Zia (1958-1969 and 1977-1988 respectively), were not empowered and had extremely limited fiscal and administrative mandates (AERC 1990). It is argued that centralisation resulted in a lack of accountability for three reasons. First, centralised service delivery and budgetary decisions created a large distance between citizens and key decision-makers, which weakened the ability of the former to monitor the actions of the latter. This factor was compounded by the absence of spatial budgeting in the old system. Budgets were prepared under a functional classification, which did not reveal the spatial allocation of funds and made it hard for areas and localities to monitor the efficiency and equity of these decisions.

The second cause of accountability failure identified by the literature was the bureaucratisation of service delivery. The majority of services were delivered through the deconcentrated provincial bureaucracy that was not electorally accountable to citizens. It was, instead, directly accountable to the higher tier provincial bureaucracy and only indirectly accountable to the provincial politicians. This created a disjuncture between service providers and citizens, weakening the accountability of the former to the latter.

The third cause of accountability failures lay in the political system, which, according to the literature, was based on a system of administrative patrimonialism and political clientelism that led to the personalisation of politics in the hands of historically entrenched elites. In this case, national and provincial politicians negotiated with local level patrons to provide votes and other benefits, which were purchased through the diversion of development funds from the provincial and federal levels (Gazdar 2000). The real political bargaining game over the distribution of development funds occurred not between citizens and their elected representatives but, rather, between local patrons and the higher-tier elected politicians and the provincial bureaucracy, and between the state and politicians.

In 2000, the new military regime of General Musharraf announced local government reforms, operationalised as the Local Government Ordinance 2001 (LGO 2001), which appeared to recognise these accountability failures. The LGO 2001 sought to redesign political, electoral and administrative structures at the local level to increase the accountability of service providers to local citizens.

However, have these reforms been effective in improving the magnitude and quality of provision of essential public services? This article attempts to explore the answer to this question by looking at survey data on the post-reform provision and quality of education and health services in four villages of Punjab. Since there is no pre-reform baseline data on service quality available for these villages, the field study sought to evaluate change through respondents' perception of pre- and post-reform provision and quality in 2004, i.e. three years after the reforms had been instituted in each province. Besides the data that our research team was able to collect in these four villages, this article also incorporates the findings of an extensive, Pakistanwide social audit carried out in the same year by Cockcroft et al. (2005), which tracks improvements in service delivery. This survey was able to track changes because of a baseline that had been set up through a similar social audit carried out in 2001/2 (Cockcroft et al. 2002). Together, the field study and the social audit should help us get a clear picture of the changes in service delivery after the implementation of LGO 2001.

However, before examining the impact of the local government reforms, this article first outlines the main changes introduced by LGO 2001 to address the accountability failures that have been held responsible for Pakistan's poor performance in terms of social development. 
2 Local Government Ordinance 2001 (LGO 2001)

LGO 2001 is a dramatic and far-reaching political reform. Through a central ruling, the 200-year-old colonial system of bureaucratic control over districts by the first two tiers of government was swiftly replaced by an elected third tier that connected 110 district governments, through 334 tehsil (rural) and 62 town (urban) governments, to 6,125 union governments in the four provinces of Pakistan. Within one year, 114,418 new elected offices were created in the country at the union level, 3,264 at the tehsil level and 2,782 at the district level, ${ }^{1}$ of which 40,108 are reserved for women, another 36,734 are reserved for labourers and peasants and 6,624 are reserved for religious minorities. ${ }^{2}$ The plan, therefore, significantly enlarged the electoral arena and allowed previously marginalised groups into the equation.

The new three-tiered local government system is based on both direct and indirect elections. ${ }^{3}$ Union Administration represents the lowest tier, Tehsil/Town Municipal Administration (TMA) represents the intermediary level and District Government represents the highest tier of local government. $A$ nazim and a deputy naib nazim lead each tier. LGO 2001 decentralised service delivery and planning to the district, tehsil and union governments, instituted representative democracies at each level, placed the local bureaucracy under elected nazims at the district level, and created new mechanisms for citizen participation. The main objective of the reform was to re-orient 'the administrative system to allow public participation in decision-making' and 'the essence of this system is that the local governments are accountable to citizens for all their decisions'. Besides this, it also sought to create 'one line of authority' that led downwards from the district nazim and made the local bureaucracy accountable to elected representatives at the local level (NRB 2000)

The plan, thus, managed to empower elected officials vis-à-vis the bureaucracy, brought planning processes and service delivery mechanisms closer to the people and increased the electoral empowerment of women, minorities and peasants (Cheema and Mohmand 2003). The plan also claimed to be 'participatory', 'bottom-up' and 'peoplecentred' and promised to increase citizen voice in government decision-making processes (NRB 2000).

A historical analysis of decentralisation in Pakistan, however, reveals that local government reforms have not in the past been instituted to empower citizens or to improve service delivery. They have, instead, been instituted by military governments in order to create a loyal cadre of local politicians willing to support the continuation of military rule and the centralisation of political power. A comparison of the current reforms with those implemented by the military regimes of Generals Ayub and Zia reveal enough similarities in substance to make it possible to postulate that these reforms too may be a 'complementary institutional change in a non-representative institution's bid for centralisation of political power' (Cheema and Mohmand 2003: 26). Such an analysis, however, is beyond the scope of the current discussion. What concerns us for now is the impact of local government reforms on the provision and quality of education and health services, and to this end, it is important to look next at the specific ways in which LGO 2001 sought to deal with the accountability failures discussed above.

\section{LGO 2001 and accountability failures}

According to Charlton et al. (2003: 11-12), the LGO 2001 attempts to overcome the accountability failures described above by:

- injecting new blood into a political system considered to be the domain of historically entrenched interests

- providing positive measures enabling marginalised citizens - women, workers, peasants - to access formal politics

- introducing a measure of stability into a turbulent political scene by creating a stronger line of accountability between new politicians and local electorates

In order to achieve these objectives a number of changes have been instituted in the structure of the law and the state. First, key provincial functions have been devolved to the district and tehsil levels so that budgeting, planning and development functions that were previously performed by provincial secretariats have been transferred to the district and tehsil levels. The scope of district governments has been increased through the devolution of services, such as primary and secondary education, primary healthcare and planning and designing of roads and buildings, while services provided by the Housing, Urban Development and Public Health Engineering departments have been devolved to the tehsil level. This reform in itself has 
Table 1 Citizen participation and oversight bodies

\begin{tabular}{|c|c|c|c|}
\hline & Composition & Elections & Functions and responsibilities \\
\hline $\begin{array}{l}\text { Village and } \\
\text { Neighbourhood } \\
\text { Councils (VNCs) }\end{array}$ & $\begin{array}{l}\text { A total of } 5-11 \\
\text { members, } 1 \text { seat } \\
\text { reserved for female } \\
\text { representative and } 1 \\
\text { for a peasant }\end{array}$ & $\begin{array}{l}\text { Independently elected } \\
\text { council under the } \\
\text { supervision of TMA. } \\
\text { Headed by a chairman } \\
\text { who secures highest } \\
\text { votes }\end{array}$ & $\begin{array}{l}\text { Development and provision of water } \\
\text { and sanitation facilities } \\
\text { Organise cultural and recreational } \\
\text { activities } \\
\text { Maximise community involvement in } \\
\text { various activities for the betterment of } \\
\text { the village } \\
\text { Act as a channel and support for Union } \\
\text { - Administration } \\
\text { Collect revenue and taxes }\end{array}$ \\
\hline $\begin{array}{l}\text { Citizen } \\
\text { Community } \\
\text { Boards (CCBs) }\end{array}$ & $\begin{array}{l}\text { Any number of } \\
\text { individuals. A village } \\
\text { can have more than } \\
\text { one CCB }\end{array}$ & $\begin{array}{l}\text { Composed of voluntary } \\
\text { members who elect a } \\
\text { chairman, executive } \\
\text { committee and a } \\
\text { secretary, each for a } \\
\text { term of } 2 \text { years }\end{array}$ & $\begin{array}{l}\text { - Development and improvement of } \\
\text { service delivery } \\
\text { - Welfare and social activities } \\
\text { - Coordinating with NGOs } \\
\text { - Raising funds }\end{array}$ \\
\hline $\begin{array}{l}\text { Musalihat } \\
\text { Anjuman }\end{array}$ & $\begin{array}{l}\text { A total of } 3 \\
\text { members }\end{array}$ & $\begin{array}{l}\text { All members, including } \\
\text { the convener, are } \\
\text { selected by the Insaaf } \\
\text { committee formed by } \\
\text { the Union Council }\end{array}$ & $\begin{array}{l}\text { - Resolve local disputes with the help of } \\
\text { the union nazim } \\
\text { - Act as a mediator for legal disputes } \\
\text { - Courts can pass cases to the Musalihat } \\
\text { Anjuman and vice versa }\end{array}$ \\
\hline $\begin{array}{l}\text { School } \\
\text { Management } \\
\text { Committees } \\
\text { (SMCs) }\end{array}$ & $\begin{array}{l}\text { A total of } 11 \\
\text { members }\end{array}$ & $\begin{array}{l}\text { Selection by } \\
\text { headmasters in informal } \\
\text { consultation with union } \\
\text { nazim/village influential }\end{array}$ & $\begin{array}{l}\text { - Expansion and development of } \\
\text { education at grassroot level } \\
\text { - Support for maintenance of school } \\
\text { facilities and management of funds } \\
\text { - Monitoring of teachers } \\
\text { - Coordinating with headmasters }\end{array}$ \\
\hline
\end{tabular}

Source Naqvi (2004).

significantly reduced the gap between service providers and citizens, which is expected to improve accountability through better citizen monitoring.

Second, provincial line departments at the district and tehsil levels have been placed under the authority of elected governments at these levels. This has significantly empowered the local level elected tier and created a new form of accountability for the provincial bureaucracy. Thus, the local level bureaucracy, which was previously accountable to unelected provincial bureaucrats, is now accountable to an elected representative of the citizens.

Third, local government reforms have also provided for institutional arrangements that foster citizen participation in service delivery and oversight. Bodies such as the Citizens Community Board (CCB) and the Village and Neighbourhood Council (VNC) have been created to enable citizens to directly participate in service delivery. Oversight bodies, such as School Committees, have been created to empower citizens as 'users' by giving them the authority to monitor and supervise local service providers. Both types of bodies have the potential to increase the accountability of government service providers to the needs of citizens (Table 1).

Finally, the strengthening of the directly elected union council as a foundation of the local state means that the old local level unelected patron may now be exposed to electoral competition and, thus, 


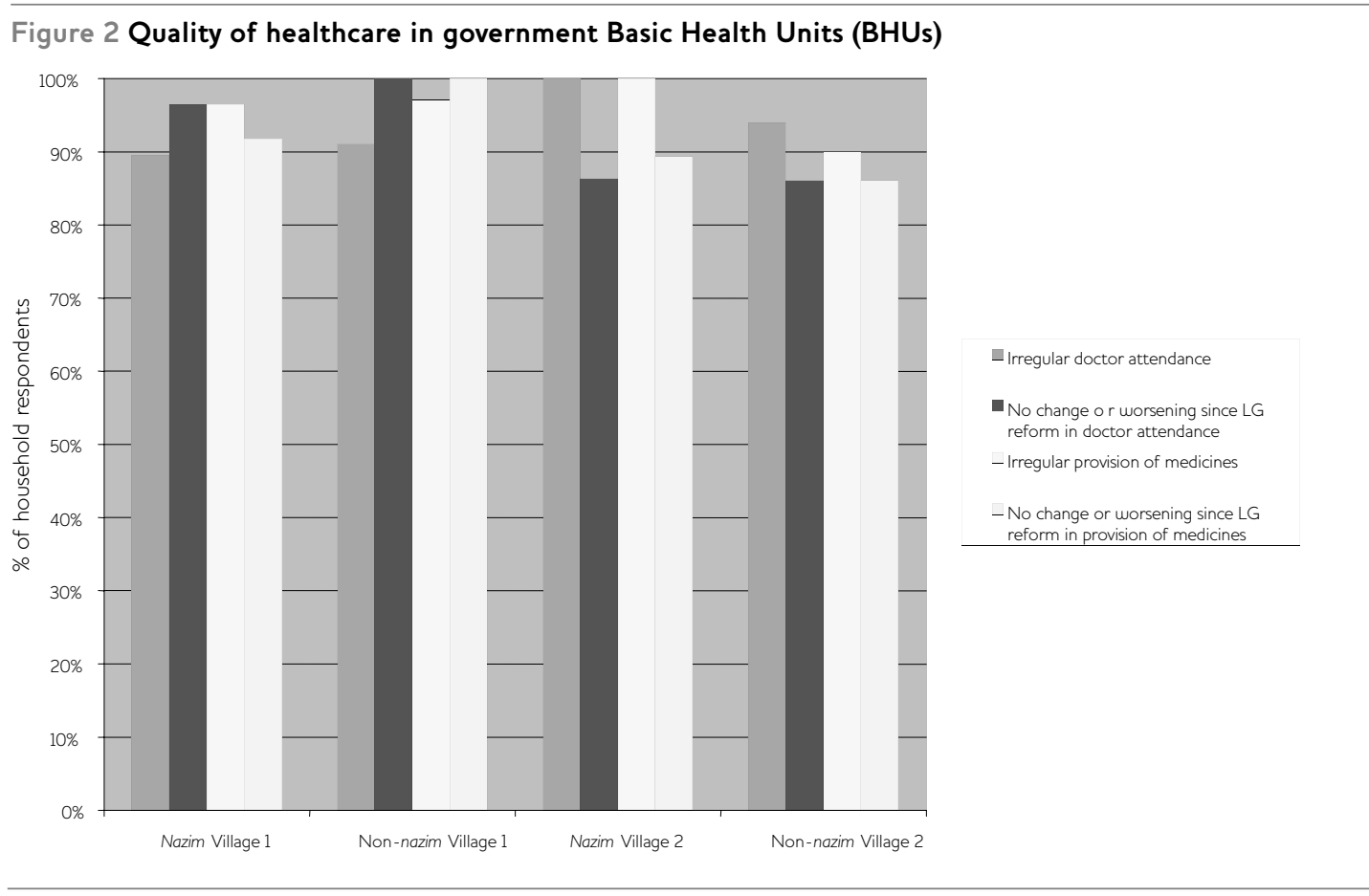

a direct link of accountability between these patrons and the union level citizenry will be created. It is also hoped that accountability to the marginalised and powerless will be further increased through the mechanism of reservation of seats in the union council for women, peasants and minorities.

These reforms have also changed the nature of political bargaining over development funds. For one, they have reduced the level at which the bargaining over development funds used to take place. In the previous system, the site of bargaining was the province, whereas now it is the district and the tehsil. More importantly, the reforms have dismantled the old system where the local patron indirectly bargained over development funds through higher tier elected politicians. Under the new system, union nazims and naib nazims can bargain directly with district and tehsil nazims in their capacity as district and tehsil councillors. ${ }^{4}$ This change empowers the union nazim and naib nazim because they have become critical providers of union level information into the local government planning process.

These reforms have clearly sought to address accountability failures in Pakistan's political and administrative structure. The extent to which they have been successful in improving the quality and provision of essential public services is examined in the next section with the help of survey data.

\section{Changes in post-reform provision 4.1 Sampling strategy}

The focus of this article and our research is on rural areas because of a higher incidence of poverty in these areas and because, despite the fact that 70 per cent of all Pakistanis live in rural areas, social service provision has always been much worse in these parts compared with urban areas. In choosing a case district, we felt that it would be instructive to analyse the impact of devolution in rural areas that have seen considerable socioeconomic change as a result of urbanisation and industrialisation. Therefore, we chose a fieldwork site in Faisalabad, Punjab's second most industrialised and urbanised district. Within Faisalabad, we chose Jaranwala tehsil because it is dominated by peasant proprietors, rather than large landlords and, therefore, can be expected to have more competitive elections and more responsive representatives. Within this tehsil, we chose two rural unions that were close to major market activity and opportunities for industrial and service sector employment. More importantly, we chose unions where the union nazim had won the 


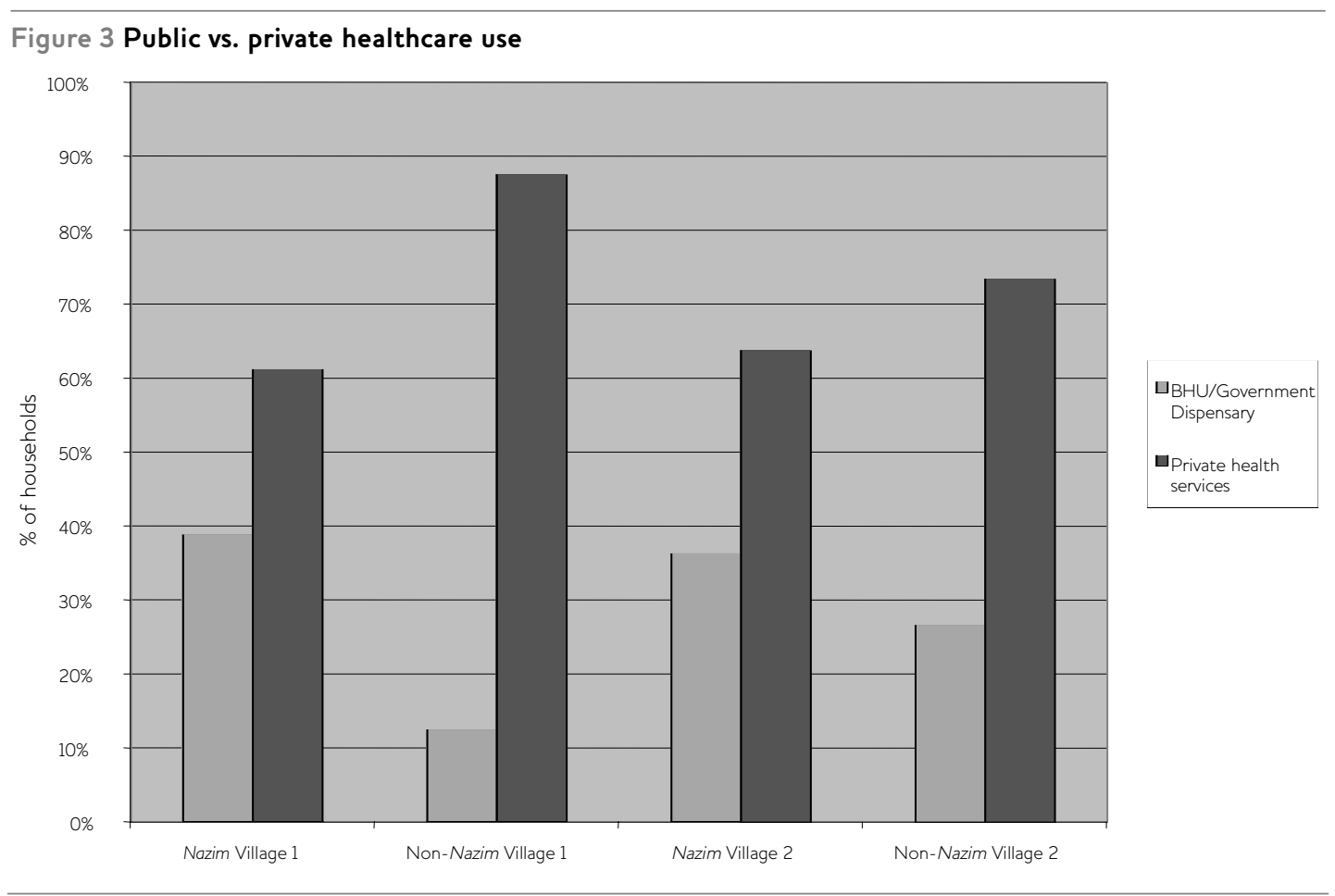

2001 local government elections by an extremely small margin so that we could expect the nazim to be responsive to citizens on account of the threat of being ousted by a small 'vote swing' in the next elections. In order to maintain the confidentiality of our respondents, we label the first union, 'Case UCl' and the second union, 'Case UC2'.

In each of these unions, we surveyed two villages. The first village chosen in each union was the elected union nazim's village because local interviews as well as international literature (Besley et al. 2004) suggest that locally elected mayors tend to oversupply their own villages at the expense of other localities. We refer to these villages as nazim Village 1 (in Case UCl) and nazim Village 2 (in Case UC2). The second village in each union was chosen on the basis of having the least or no representation on the union council. These villages are labelled non-nazim Village 1 (in Case UCl) and non-nazim Village 2 (in Case UC2). In each village we surveyed 22-30 per cent of households, which gave a total sample of 364 households. The household sample was randomly drawn and stratified according to the biraderi $1^{15}$ composition of the village, based on the fact that biraderis are considered good proxies for social positions. ${ }^{6}$

\subsection{Has the quality of healthcare improved?}

State-provided healthcare is an important need demanded by the citizens of our case unions. Stateprovided Basic Health Units (BHUs) are in existence in both our case unions and their provision was made prior to the recent local government reforms. In line with our concern in this article, we ask whether there has been an improvement in the quality of health provision by $\mathrm{BHUs}$ since the recent local government reforms. We measure the quality of state-provided healthcare along two dimensions. The first is doctor attendance and the second is the availability of medicines. In this regard, respondents were asked to rank doctor attendance and medicine availability on a scale that ranged from ' 1 ' (no attendance or medicine availability), to '5' (regular attendance and availability). Figure 2 shows that, across our sample villages, 90-100 per cent of our respondents who regularly use the $\mathrm{BHUs}$, report irregularity of doctor attendance and medicine availability. ${ }^{7}$ This suggests that serious shortfalls exist in the quality of state-provided healthcare at the union level.

To gauge how local government reforms have impacted the quality of state-provided healthcare, we asked our respondents to rank changes in the quality 


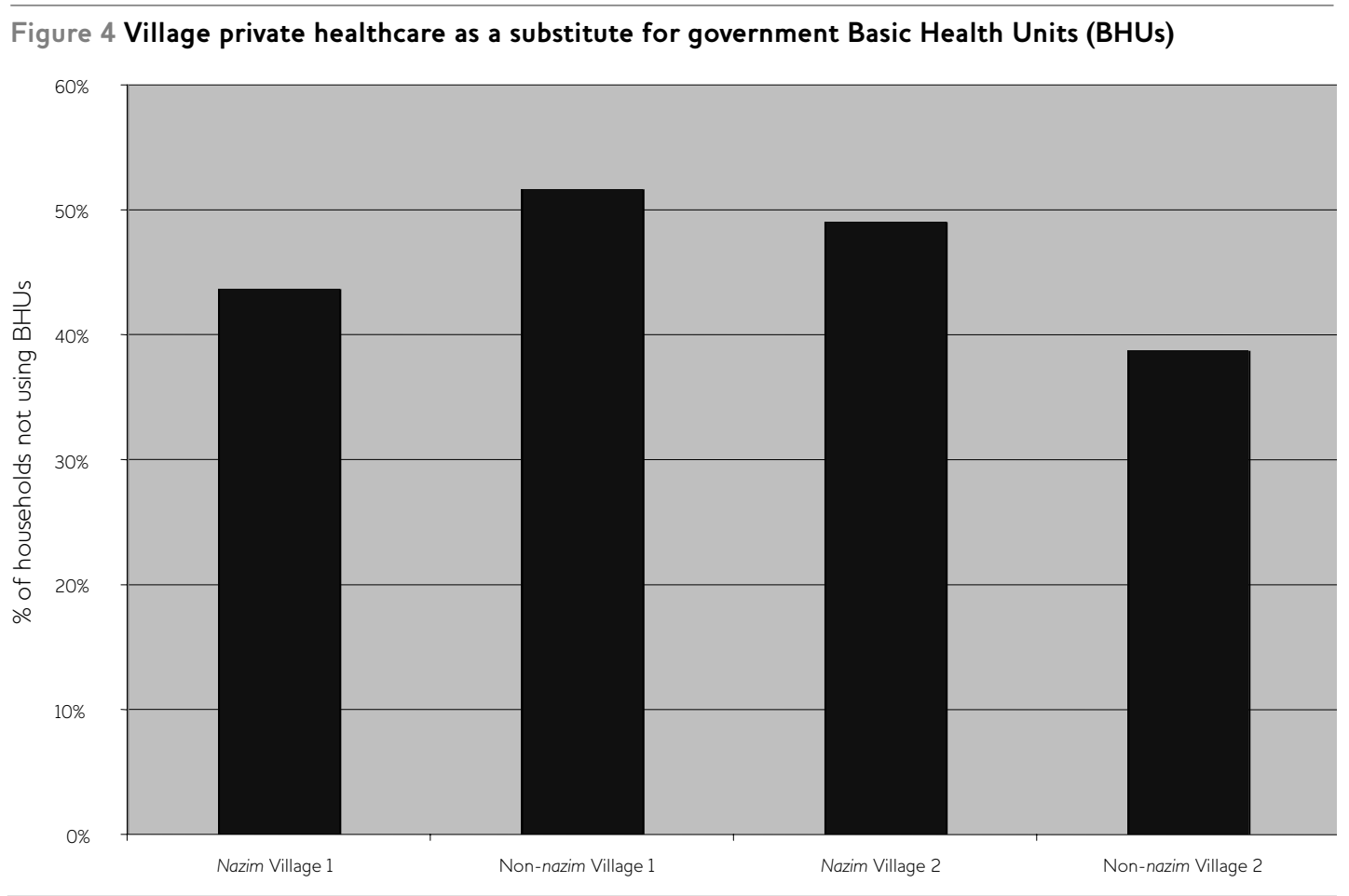

of the above indicators since local government reforms. A score of ' 1 ' reflects serious worsening, a score of ' 3 ' implies no change and a score of ' 5 ' means an improvement. Figure 2 shows that, across our sample villages, 80-100 per cent of our respondents who regularly use the $\mathrm{BHUs}$ report no change or a worsening in the quality of healthcare ${ }^{8}$ since local government reforms. Taken together, this analysis suggests that the poor quality of healthcare, a predevolution outcome, has persisted since the reform.

Interestingly, nazim Villages 1 and 2 have fared almost as badly as the two non-nazim villages. This indicates that having a resident nazim makes no real difference in the delivery of a universal service such as health. It seems that villages that are well represented on the union council, in this case by the top-most union executive who is able to bargain at the district level, are as badly off as villages that are poorly represented (non-nazim Village 2) or not represented at all (non-nazim Village 1). The reason why union executives appear to be irrelevant to the provision of universal services is analysed later in this article.

A result of poor provision of state-provided healthcare is that union level citizens are 'voting with their feet' (going elsewhere) in favour of private healthcare (Figure 3). Over 60 per cent of the respondents in our sample villages suggested a preference for private healthcare over state-provided healthcare. Typically cited reasons for this preference include better availability of doctors and medicines in private clinics. This suggests that respondents are discriminating in favour of private healthcare on the basis of availability of medicines and doctors and not on the quality of doctors or diagnosis. This reflects the sheer poverty of state-provided healthcare in Pakistan. Proximity to a health facility also plays a part. The higher usage of a state-provided health facility in nazim Villages 1 and 2 is heavily influenced by the fact that both these villages are also the headquarter villages of the union and, therefore, they have a BHU. Such a facility is lacking in the other two villages and is reflected in their lower usage of state-run facilities and their higher usage of private facilities.

Private healthcare as a solution, however, has a number of problems associated with it. The most important being access to quality private healthcare. Figure 4 shows that 40-50 per cent of citizens opting out of state-provided healthcare actually end 
Table 2 Dependence on village level private healthcare

Likelihood of using village level private healthcare (\%)

Village influentials' biraderi in all villages

$-13.5^{*}$

Small farmer and low caste biraderis in non-nazim villages 13.6**

Small farmer $\left(<5\right.$ acres) in nazim's Village $2 \quad 26.6^{*}$

*Significant at $5 \%$ level. ${ }^{* *}$ Significant at 10\% level.

up using village level private healthcare. Village level intervieus revealed that this system is run by unqualified and untrained compounders and medicine salesmen, and not by trained doctors. Therefore, the poverty of the state-provided healthcare system is forcing a large majority of citizens to turn to poor-quality private healthcare.

Furthermore, Table 2 shows that small farmers and lower caste biraderis have a much higher reliance on poor-quality village level private healthcare. Small farmers in nazim Village 2 have a 26 per cent higher chance of using village level private healthcare than others in the village. Similarly, low caste biraderis in our non-nazim villages, who are mostly labourers and domestic servants, have a 14 per cent higher chance of using village level private healthcare. In contrast, belonging to the dominant biraderi in the village, that is the biraderi of the village influential, reduces reliance on village level private healthcare. Therefore, the current system of state-provided healthcare is largely penalising small farmers and lower caste biraderis who clearly cannot afford to use the better quality urban healthcare system available in the town nearby. The elite biraderis are not as badly affected by the poor provision of state-provided healthcare, possibly because it is easier for them to substitute urban private healthcare for union level stateprovided healthcare due to better information and/or better resources. The failure of state-provided healthcare at the union level is creating disparities of access for socially and economically weaker groups and no change is observable in the quality of stateprovided healthcare since the inception of the recent local government reforms in our sample unions.

Cockcroft et al.'s (2005) findings for the country as a whole support the findings in our case villages, though they also find positive results for some indicators of quality. First, satisfaction with stateprovided health services increased in three out of four provinces between 2002 and 2004 (from 65 per cent to 68.6 per cent). An extremely positive finding for decentralisation was the fact that users were more likely to report satisfaction if the health facility was directly monitored by the union nazim or councillors. Second, more people felt that they had access to state-provided health services in 2004 (76.6 per cent vs. 66.8 per cent in 2002). Third, more people felt that they knew how to complain about state-run health facilities (11.8 per cent in 2002 vs. 16.1 per cent in 2004) (Cockcroft et al. 2005: 77-84).

However, despite the increase in satisfaction, the use of these facilities actually decreased according to the survey (from 29.2 per cent in 2002 to 23.9 per cent 2004). As is the case in our villages, this decrease in usage was particularly high in the 'vulnerable and very vulnerable'g households, which were also less likely to report satisfaction with the services they had access to, compared with other groups. The decrease in use occurred mostly in communities that were more than $5 \mathrm{~km}$ from the nearest state-run health facility. Another major reason for reduced use was the lack of availability of medicine, which has remained an acute problem, with less than 30 per cent reporting that they received all their required medicines from the facility, despite an improvement being reported across 50 per cent of the facilities visited during this survey (Cockcroft et al. 2005: 78-83).

Two out of three users of state-provided health facilities had to pay more for an entry ticket to access the facility in 2004 than in 2002, and about 60 per cent of users said they paid more than twice the official rate. This is another important reason for why people are opting to use private health services, usually run by unqualified practitioners, that are available easily and cheaply within the village. Interestingly, these were most popular in Punjab in both years, with 35 per cent opting to use unqualified practitioners in 2002, and 39.3 per cent 


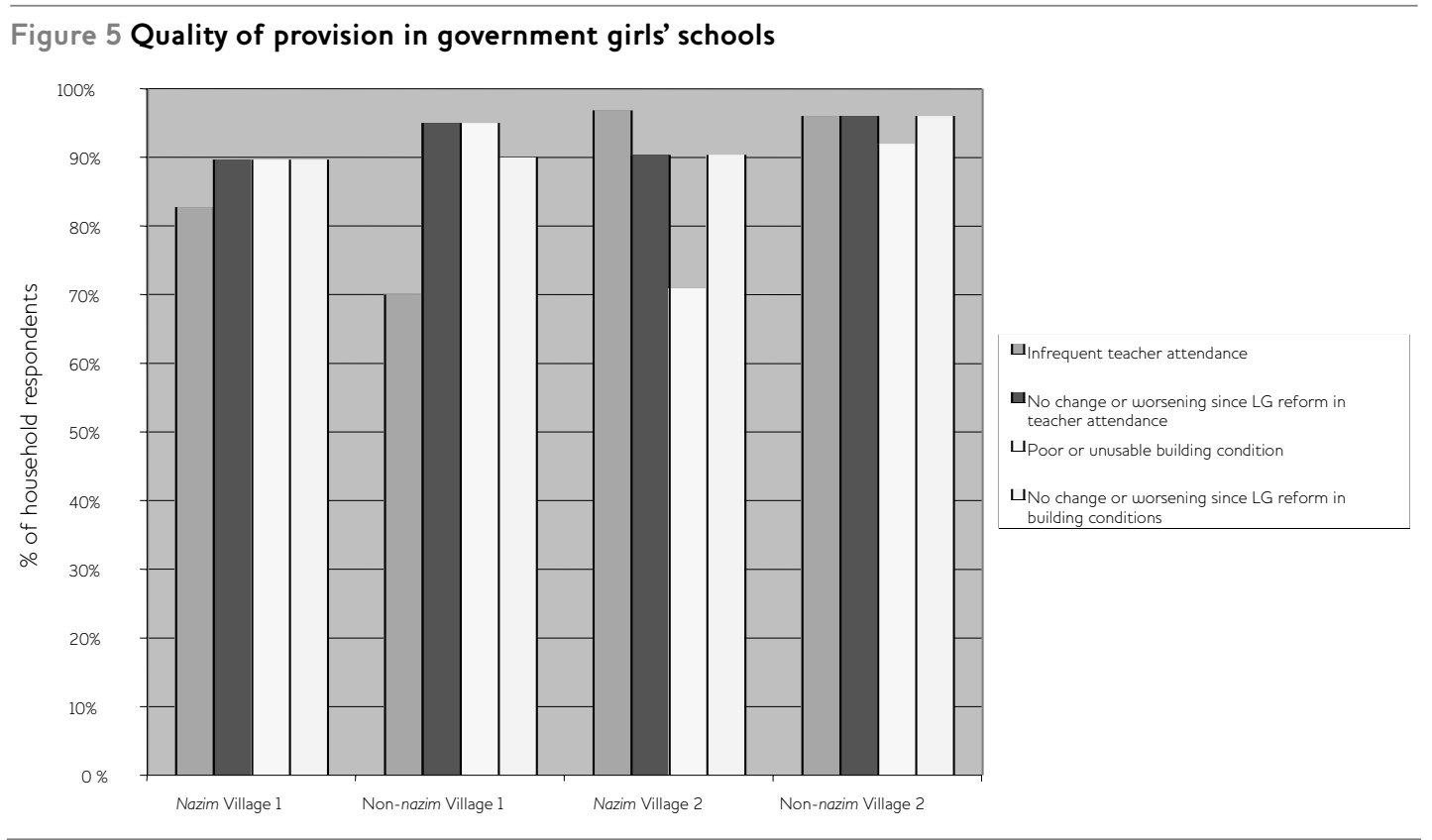

opting to do so in 2004. The rate of satisfaction reported for private practitioners was also much higher than that reported for doctors in state-run facilities. An important finding of the study is that the decrease in the usage of state-run facilities is almost exactly matched by the increase in the use of unqualified practitioners, so that all those that opt out of state facilities are going straight to unqualified practitioners rather than to private, qualified doctors. Unfortunately, our finding that the poverty of the state-provided healthcare system is forcing a large majority of citizens in our case villages to turn to poor-quality private healthcare is true for the country as a whole (Cockcroft et al. 2005: 78-81).

\subsection{Has the quality of education improved?}

Like state-provided healthcare, education is an important need demanded by the citizens of our case unions. Male and female state-run primary schools are in existence in both our case unions, and their provision was made prior to the recent local government reforms. Between 70 and 100 per cent of children attending primary schools in these villages are using a government school, which means that the quality of state provision will be an important factor determining the future of the young in these villages. In line with our methodology for healthcare, we ask whether there has been an improvement in the quality of state-provided primary education since the recent local government reforms. We measure the quality of state-provided primary education along two dimensions. The first is teacher attendance and the second is the condition of school buildings and facilities. In this regard, respondents were asked to rank teacher attendance and the condition of buildings and facilities on a scale that ranged from ' 1 ' (no attendance or dilapidated conditions) to ' 5 ' (regular attendance and a well-functioning facility). We present the results separately for girls' and boys' primary schools.

\section{Government girls' primary schools}

Figure 5 shows that, across our sample villages, 70-95 per cent of our respondents who use government primary girls' schools report irregularity of teacher attendance and a poor or unusable condition of facilities. ${ }^{10}$ This underscores the poor state of primary education provision at the local level.

To gauge how local government reforms have impacted on the quality of state-provided girls' primary education, we asked our respondents to rank changes in the quality of the above indicators since local government reforms, on the same 1 to 5 scale. Figure 5 shows that, across our sample villages, 90 per cent of our respondents who are users of government girls' primary schools report no change or a worsening in the quality of education ${ }^{11}$ since local government 


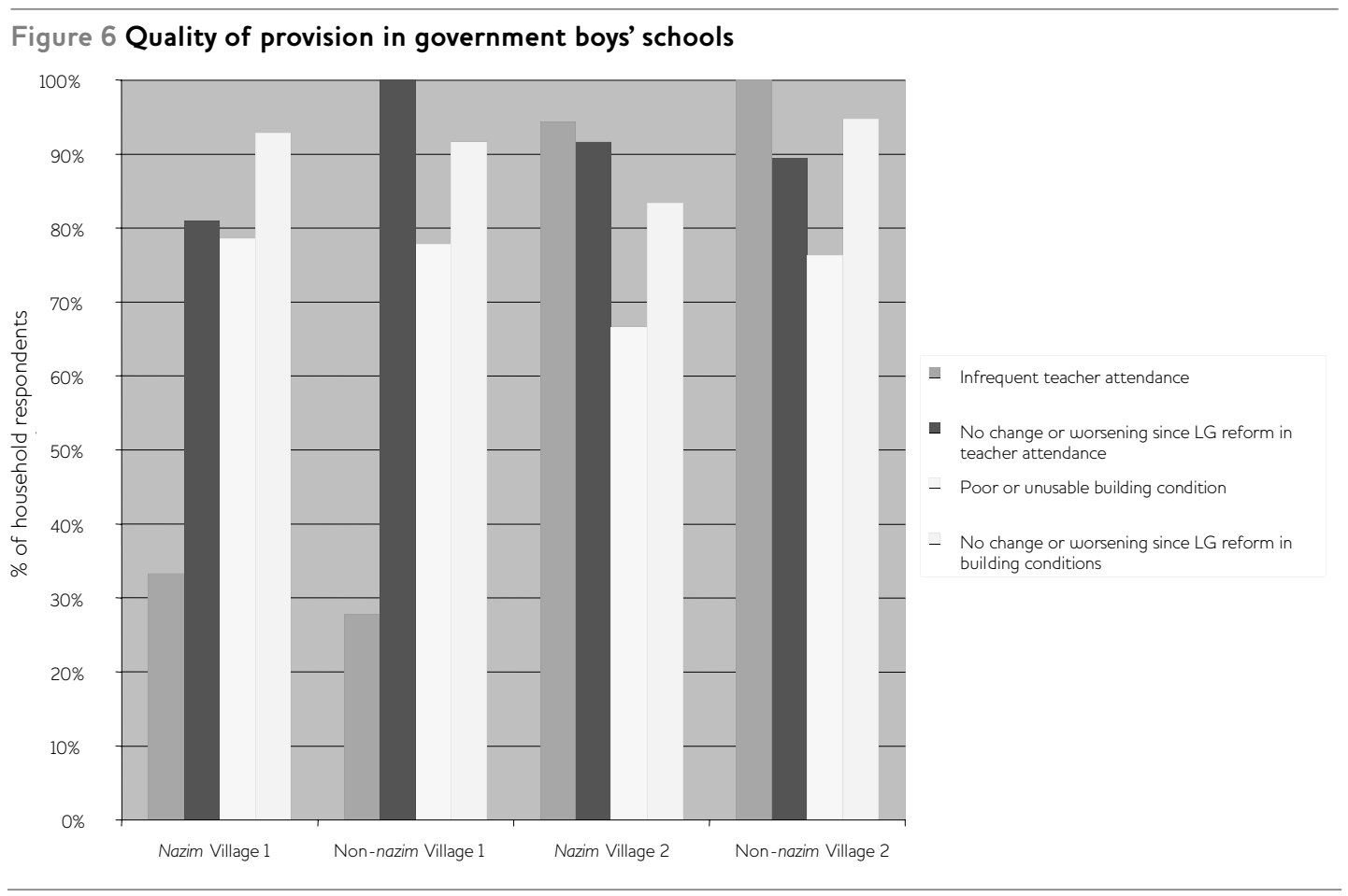

reforms. As in the case of health, taken together, this analysis suggests that the poor quality of governmentprovided girls' primary education, a pre-devolution outcome, has persisted since the reform. It is also obvious, once again, that representation on the union council appears to have no particular impact on the provision of primary education services.

\section{Government boys' primary education}

Unlike girls' primary schooling, there is variation in teacher attendance in government boys' schools between our two union councils, with Case UC1 doing much better than Case UC2 (Figure 6). The number of respondents reporting infrequent teacher attendance ranges between 90-100 per cent for our two sample villages in Case UC2. However, the picture regarding the condition of school facilities is as dismal for government boys' schools as it is for government girls' schools, with 70 per cent of sample respondents reporting poor or unusable facilities in all our sample villages. A majority of respondents also report either 'no change' or 'worsening' in teacher attendance and the condition of school facilities, since local government reforms. Once again no changes are observable in the quality of schooling indicators for these schools since the reform, even though serious quality shortfalls exist in these schools. Interestingly, unions do well or badly as a whole, and representation on the union council appears to have little impact on service delivery.

Once again, Cockcroft et al.'s (2005) survey findings for Pakistan are not very different from those of our case villages. There was no change in the satisfaction with state-provided education reported in 2002 (54.1 per cent) and 2004 (53.3 per cent). In terms of usage, however, unlike the health sector, more people tend to use government schools than private schools, though the latter experienced a relatively greater increase in enrolment (Cockcroft et al. 2005: 88-90).

Looking at findings that are comparable with the two main indicators of quality that we used in our case villages - teacher attendance and the condition of school buildings - we find that the quality of teaching is suffering all over the country and that there has been little change since the local government reforms. Of all those that chose to send their children to government schools, only 13.6 per cent said that it was because of the quality of the teachers, compared with 44.7 per cent of those that chose private schools instead. Similarly, as far as the 


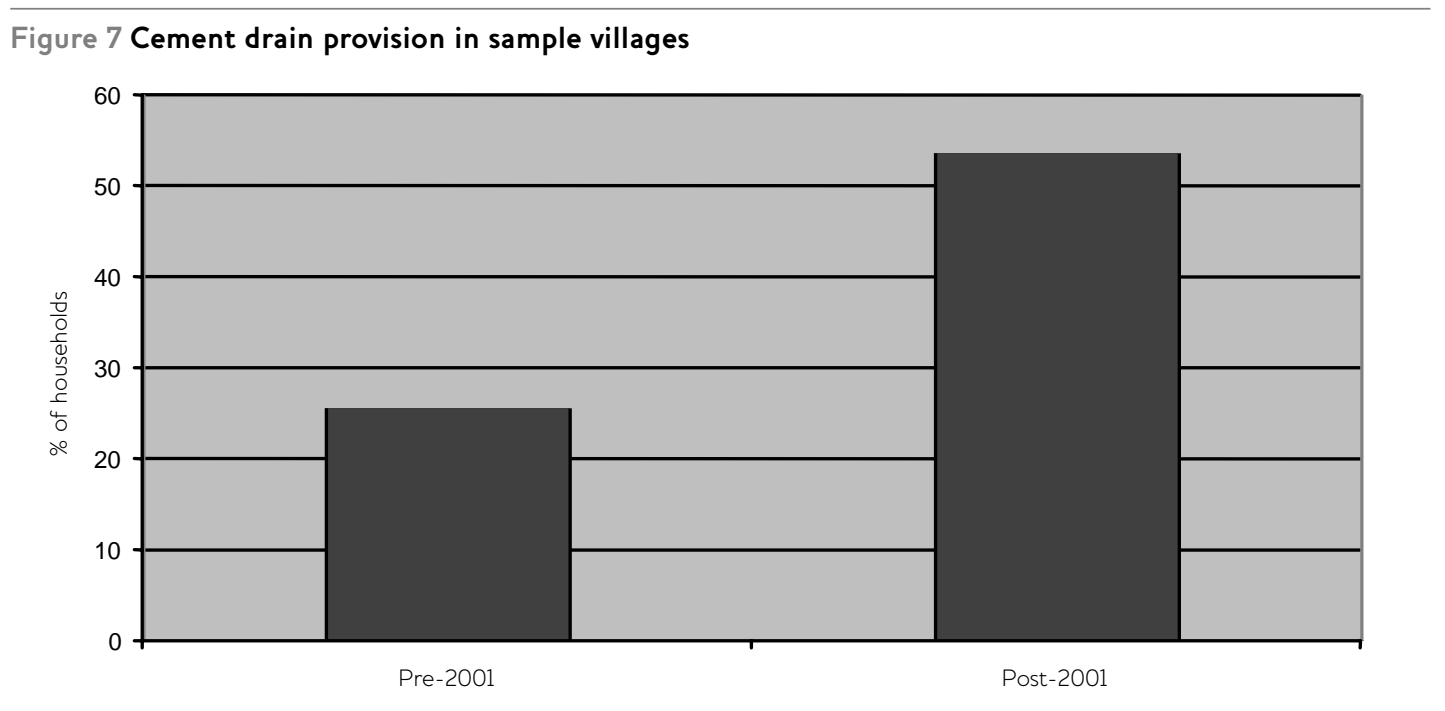

facilities were concerned, an even lower proportion of parents who had chosen government schools mentioned these as a deciding factor (4.4 per cent), as opposed to 21.7 per cent of those whose children were in private schools. The most compelling reason for choosing a government school was proximity and accessibility (43.6 per cent) and low fees and incentives such as scholarships, free books and uniforms (27.9 per cent) (Cockcroft et al. 2005: 94).

On the positive side, only 4.1 per cent said they had no access to state-provided education in 2004, compared with 7.4 per cent in 2002, indicating a possible increase in services between these years. This is supported by an overall increase in the perception of access in all four provinces. However, proximity to a government school was correlated with higher satisfaction only in the case of government girls' schools, which is an intuitively obvious finding, given that we found that parents are unwilling to send daughters to attend schools in other villages. Like Cockcroft et al. (2005), we too found that not being able to send their daughters to school within their own village was a very significant complaint of many respondents, and that while boys had the option of attending school in nearby villages, the lack of a girls' school in a village, or the existence of one with poor teaching quality, meant that girls may not get educated at all (Cockcroft et al. 2005: 88-90).

Our research shows that the poor-quality provision of universal services adversely affects the lives of not only ordinary citizens but also differentially affects the lives of girls, small landholders and low caste biraderis in our sample villages. Girls are worse off because the shortfall in teacher attendance is much more severe in government girls' schools than it is in government boys' schools, and because they do not have alternative options. Small landowners and low caste biraderis are worse off because they lack access to urban private healthcare and their only available response to declining state healthcare provision is to switch to low-quality village level private healthcare. They do not have the luxury to effectively 'vote with their feet' in the face of declining quality of state healthcare.

\section{Conclusion}

The results presented above on the provision of health and education services show that decentralisation has not led to any real improvement in the provision or the quality of these services. Our initial premise was that Pakistan's social development has suffered due to accountability failures, and that since LGO 2001 explicitly sought to address these, we would expect to find that service delivery has improved. Why, then, has this not happened?

It is instructive at this point to compare the delivery of targeted services, such as sanitation and sewerage, with that of universal services, such as education and health, in our case villages. The same survey that we used to assess health and education changes also checked for the provision of and change in the quality of sanitation drains. Figure 7 shows that there has been an impressive change in government-provided sanitation to households since 
Figure 8 Cement drain provision by village type

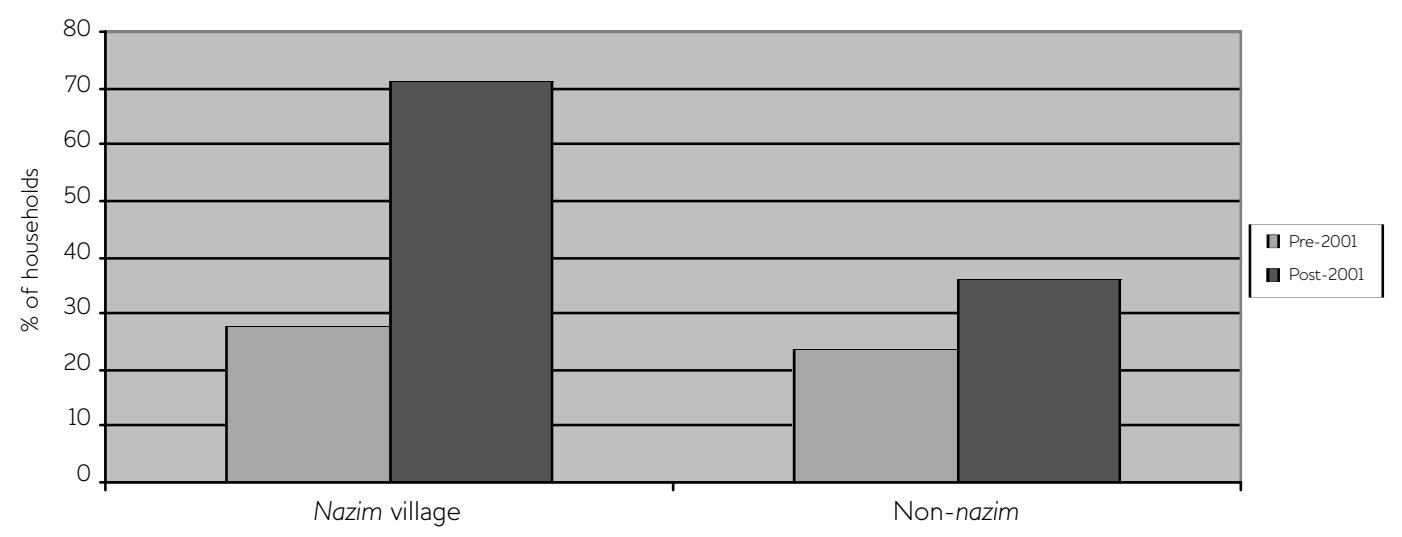

the reforms. State-provided cement drain services to households has increased by approximately 28 per cent over the pre-reform level. This is largely because of an increased availability of funds and that union executives now have a voice in the determination of district council development funds.

While this increase is impressive, it unfortunately indicates that the old tendency of government to concentrate on the provision of targeted services in the face of declining quality of universal services is continuing. Worse still, Figure 8 shows that when this increase in provision is disaggregated by nazim and non-nazim villages, the increase has occurred almost entirely in the villages where the nazim is resident. Over 40 per cent of the households in the nazim villages have been provided drains post-local government reforms as opposed to only 14 per cent of the households in the non-nazim villages.

It appears that in the case of targeted services having a strong representation on the union council, or at least a resident nazim, makes the difference. Interestingly, the provision deficit comparison between the nazim and non-nazim villages was not large prior to the reform, even though overall provision was low in all villages $^{12}$ (Figure 8). This indicates that the tendency towards parochial targeting has been exacerbated post-reform. However, why are union nazims willing to provide targeted goods to their own villages but ignore the same constituency when it comes to the delivery of universal goods?

The answer to this question is provided, partially, by the literature on elite capture, which holds that decentralisation in polarised societies can lead to the over-provision of targeted goods to local elite groups (Bardhan and Mookherjee 2006; Besley et al. 2004). This literature is useful in analysing local politics in our case villages. We found that nazims cater essentially to their own factions and that these are village-specific and do not transcend the boundaries of their own villages to encompass factions in other villages of the union (Cheema and Mohmand 2006). This may explain why union nazims may be tempted to concentrate all benefits within their own villages. These factions are also not inclusive of a wide crosssection of the village population as they are formed on the basis of biraderi alliances, so that nazims are more prone to provide services that can be targeted to specific groups, that are tangible and visible, and that are directly attributable to them. This allows them to reward their own factions and to appear to prioritise them over all others in order to retain their support. This is not possible in the case of universal services, improvements which are not only less visible and obvious, but also cannot be easily targeted to specific groups. Therefore, while the delivery of targeted services has increased under the new decentralised system, delivery of universal services has not increased because electoral accountability of the local influentials has not increased. Citizens are as yet unable to hold local level service providers accountable, either indirectly through their representatives or directly through participation in citizen monitoring and oversight bodies.

Our interviews with union council nazims in our case unions, however, suggest that nazims were fully cognisant of the poor quality of universal services 
and of the failure of the system to improve quality post-local government reforms. In the view of the union council nazims, the failure of accountability does not reside at the union level but at the district level. They pointed out that the union is a unit that enjoys little decision-making power vis-à-vis the district and tehsil and therefore cannot affect decisions taken at that level. The responsiveness of the union nazim is severely curtailed by the fact that he/she has limited authority over the delivery of universal services. The level that can take decisions regarding these services - the district and to a lesser extent the tehsil - is de-linked from citizens and thus has little perception of their needs. This is because little has changed in the administrative procedures of accountability and because elected higher tier nazims are governed by the imperatives of a system of indirect elections. Both the district and tehsil nazims are elected by union councillors and not by the tehsil or district citizens. Therefore, the agents in charge of accountability of local service providers have no direct link with citizens that require these services. Furthermore, indirect elections imply that district and tehsil nazims need to be responsive only to their own very limited direct constituency of about 1,200 councillors and not to the larger citizenry. The electoral incentives provided to higher tier politicians may provide another important reason for weak accountability of local level service providers and why the quality of universal services continues to suffer post-reform.

Union nazims also point out a number of structural constraints that inhibit them from holding local level service providers accountable. They stress that local government reforms have not been complemented by bureaucratic reforms below the district level. The chain of bureaucratic accountability below the office of the Executive District Officer (EDO) ${ }^{13}$ has not altered post-local government reforms. Therefore, union nazims, who are directly accountable to local citizens, do not have the power to discipline a local level teacher, doctor, nurse, etc. As a result, there is a disjuncture between their accountability to local level citizens and their authority to hold local level service providers accountable. In order to do the latter, union level nazims have to work through the office of the district nazim, which turns into a costly exercise because of the effort involved in having their voice heard within the district nazim and the EDO's office. As they point out, these offices receive many such complaints every day and there is no mechanism in the system that forces either the district nazim or his/her EDO to respond to the union nazims' complaints. Both the union nazims of our two case unions had lodged repeated complaints with the district government regarding the poor performance of local level service providers in charge of the maintenance and provision of state-provided health and education services but had received no response. Furthermore, they argue that the distance of the EDO's office from the locality makes it difficult for the citizen to accurately assess the real cause of poor quality and as a result, the union nazim's office bears the stigma of poor-quality provision.

As far as the role of the newly formed citizen participation bodies is concerned, there was a consensus between citizens and union nazims regarding the poor performance of school councils (SCs) in holding local level service providers accountable. SCs are post-reform school level parent oversight bodies, which have the authority to monitor teachers. SCs were operational in all government primary schools in our case unions. However, in spite of the consensus between them, citizens and union nazims gave diametrically opposite reasons for the poor performance of SCs. In the citizens' view, the process through which parents were selected as members of SCs was prone to interference by the union nazim and the head teacher. In their view, this made SCs partisan and weak as mechanisms of oversight and accountability. In contrast was the union nazim's view, that biraderi and/or factional divisions within the villages were played out within the SCs. These divisions were argued to extinguish the effectiveness of SCs as oversight bodies with this factional strife weakening them as mechanisms through which local service providers could be held accountable. Village level factional strife may also explain why villagers find it hard to unify and organise collective action around issues of poor-quality universal public service provision.

Based on all of these factors, LGO 2001, despite aiming to correct accountability failures in Pakistan's administrative and political systems, has not yet managed to achieve this aim. This article has attempted to rigorously measure the impact of Pakistan's recent local government reforms on changes in the quality of service provision, and found that while the provision of targeted services has increased, the reforms have not been able to improve the quality or provision of universal services. 
This may be because the reforms are still recent and may need time to correct many of these failures. It could also be because the implementation of fiscal decentralisation has not happened, funds are extremely limited at the local level, and the incentive for capture is high. However, the analysis presented in this section points out that the problems are not

\section{Notes}

1 These figures for the tehsil and district do not include the 6,022 union nazims in the district councils and 6,022 union naib nazims in the tehsil councils to avoid double counting.

2 During the 2001 elections and the first term of local government, each union council had 19 members. $A$ total of 12 were elected on general seats (of which four were reserved for women); six were elected on reserved labour/peasant seats (of which two were reserved for women); and one was elected on a reserved religious minority seat. However, these were reduced to 13 seats for the second round of local government elections in August-September 2005, so that they now stand at six general seats (of which two are reserved for women); four reserved labour/peasant seats (of which two are reserved for women); and one reserved religious minority seat.

3 All union councillors, union nazims and union naib nazims are directly elected. Tehsil and district nazims and naib nazims, and tehsil and district councillors on reserved seats are indirectly elected by union councillors.

4 Union nazims are ex-officio members of the district council and union naib nazims are ex-officio members of the tehsil council.

\section{References}

AERC (Applied Economic Research Centre) (1990) 'Local Government Administration in Pakistan', unpublished manuscript, Karachi: AERC

Bardhan, P. and Mookherjee, D. (2006)

'Decentralisation and Accountability in Infrastructure Delivery in Developing Countries', Economic Journal 116.508: 101, January

Besley, T., Pande, R., Rahman, L. and Rao, V. (2004) 'The Politics of Public Good Provision: Evidence from Indian Local Governments', Journal of European Economic Association Papers and Proceedings 2.2-3: 416-26, May simply those of incomplete implementation but, instead, lie to a large extent on administrative procedures and the structure of the local government plan. Therefore, these need to be reformed in order to correct accountability failures and to improve social service provision in rural Pakistan.

5 Hierarchically ordered, patrilineal kinship groups that retain an element of the occupational caste system.

6 This sampling strategy, though central to our research, is not entirely relevant to the results presented in this article, since we do not analyse the delivery of universal services at the level of the household. Its relevance is presented in the findings of a complementary paper on targeted service delivery by Cheema and Mohmand (2006).

7 A score of 3 or below.

8 A score of 3 or below.

9 Defined as a household with 'poor roof construction, high room occupancy and poor occupation of main breadwinner' (Cockcroft et al. 2002: viii).

10 A score of 3 or below.

11 A score of 3 or below.

12 Since the baseline data for new delivery was based on recall, there is the distinct possibility that our respondents classified dysfunctional drains as no delivery pre-devolution. Care was taken to control for this but this bias remains in our data to an extent.

13 The district bureaucracy is led by the District Coordination Officer (DCO), to whom an EDO for each of the district level services reports directly. The highest district bureaucrat for any particular service is, therefore, the EDO.

Charlton, J., Cyan, M., Hasnain, Z., Manning, N. Porter, D. and Sharif, H. (2003) Devolved Service Delivery Study, Washington DC: World Bank/ADB/DFID

Cheema, A. and Mohmand, S. (2006) 'Bringing Electoral Politics to the Doorstep: Who Gains Who Loses?', paper presented at the Decentralisation Task Force Meeting of the Initiative for Policy Dialogue (IPD), Columbia University, New York, USA, February

Cheema, A. and Mohmand, S. (2003) 'Local Government Reforms in Pakistan: Legitimising Centralisation or a Driver for Pro-Poor Change?', 
background paper for the Pakistan 'Drivers of Pro-Poor Change' study, conducted by Institute of Development Studies, Sussex and the Collective for Social Science Research, Karachi, for the Department for International Development UK Cockcroft, A., Andersson N., Omer, K., Ansari, N., Khan, A., Chaudhry, U.U. and Saeed, S. (2005) 'Social Audit of Governance and Delivery of Public Services - Pakistan 2004/05', National Report, Community Information Empowerment and Training (CIET) and Devolution Trust for Community Empowerment (DTCE), Islamabad

Cockcroft, A., Andersson, N., Omer, K., Ansari, N., Khan A. and Chaudhry, U.U. (2002) Social Audit of Governance and Delivery of Public Services - Baseline Survey 2002: National Report, Community Information Empowerment and Training (CIET) and National Reconstruction Bureau (NRB), Islamabad

Easterly, W. (2003) 'The Political Economy of Growth Without Development: A Case Study of Pakistan', in D. Rodrik (ed.), In Search of Prosperity: Analytical Narratives on Economic Growth, Princeton, NJ: Princeton University Press
Gazdar, H. (2000) 'State, Community, and Universal Education: A Political Economy of Public Schooling in Rural Pakistan', unpublished manuscript, London School of Economics: Asia Research Centre

Guha-Khasnobis, Basudeb and Bari, Faisal (2003) 'Sources of Growth in South Asian Countries' in Isher Ahluwalia and John Williamson (eds), The South Asian Experience With Growth, New York: Oxford University Press: 13-79

Naqvi, A.A. (2004) 'Targeted Service Delivery in Pakistan: The Impact of Decentralization', Masters thesis, Department of Economics, Lahore University of Management Sciences, Lahore NRB (National Reconstruction Bureau), Government of Pakistan (2000) Local Government - Devolution of Power and Responsibility: Establishing the Foundation of Genuine Democracy, www.nrb.gov.pk UNDP (United Nations Development Programme) (2005) Human Development Report, Oxford: Oxford University Press 